\title{
On the Effectiveness of Applying English Poetry to Extensive Reading Teaching
}

\author{
Fanmei Kong \\ English Department, Dezhou University, Dezhou City, China \\ Email: fanmeikong08@126.com
}

\begin{abstract}
English poetry plays an important role in fulfilling the goals of extensive reading teaching, but English poetry teaching is less than satisfactory in extensive reading teaching due to learners' attitude and traditional teaching methods and so on. Therefore, this thesis makes a study of the effectiveness of applying English poetry to extensive reading teaching from two aspects: the characteristics of English poetry and the functions of English poetry in extensive reading teaching. And in the end, this thesis puts forward some suggestions for how the teacher appropriately makes use of English poetry in extensive reading teaching.
\end{abstract}

Index Terms-English poetry, extensive reading teaching, characteristics of English poetry, functions of English poetry, effectiveness

\section{INTRODUCTION}

Extensive reading is one of courses to develop learners' language proficiency. The goals of extensive reading teaching are: to enlarge learners' vocabulary, to develop learners' reading comprehension and skills, to raise learners' cultural and intercultural awareness, to cultivate learners' logical thinking ability and so on. Someone thinks the ultimate goal of extensive reading is to produce independent and critical readers or to prepare students to be maximally effective in real life reading or to 'transfer' what they have learned into real life reading (Hamers and Csapó, 1999). The author thinks the ultimate goal of extensive reading teaching is to improve learners' creativity and self-cultivation and the author also believes that English poetry will play an important role in fulfilling the goals of extensive reading teaching if English poetry is properly used in teaching.

However, English poetry is often excluded from extensive reading materials and even though some poems have been selected and used as texts in some extensive reading textbooks, poetry teaching is less than satisfactory in extensive reading teaching. On one hand, in modern society, most learners are learning for a living or just to meet social need. They become indifference to the art and don't think it does much good to spend much time on reading English poetry. Even if someone might be attracted by poetic language, they would sacrifice their 'personal needs' for a 'bright' future. Even when they are taught English poems, they just listen to the teacher who helps learners solve linguistic puzzles. On the other hand, many teachers still focus too much on lexical and grammatical points or pay much attention to limited practice in various reading skills and strategies but give less attention to the development of learners' creativity and moral integrity which the essential-quality-oriented education stresses. So English poetry teaching becomes something like solving linguistic puzzles with the result that the aesthetic effects of English poetry can not be fully appreciated by learners who have no interest in poetry at first or will lose interest in learning English poetry.

Actually, English poetry, with its aesthetic values, is very useful reading material if it is used in an appropriate way. This thesis will carry out a study of effectiveness of applying English poetry to extensive reading teaching from the following aspects: the characteristics of English poetry and the functions of English poetry in extensive reading teaching.

\section{THE CHARACTERISTICS OF ENGLISH POETRY}

English poetry is the essence of English literature. According to Oxford English Dictionary (XI), poetry may be defined as the expression or embodiment of beautiful or elevated thought, imagination, or feeling, in language adapted to stir the imagination and emotion, both immediately and also through harmonic suggestions latent in or implied by the words and connections of words actually used... Poetry is a form of literary art in which language is used aesthetically and evocatively. Poetry often uses particular forms and conventions to suggest alternative meanings in the words, or to evoke emotional or sensual responses, and to achieve aesthetic effects as well. The following part will mainly focus on three characteristics of poetry: musical sound effects, concise expressions and rich images.

\section{A. Musical Sound Effects}

Poetry is closely related with music. Just as Edgar Alan Poe states that "Poetry is music which is combined with a pleasurable idea, the rhythmical creation of beauty in words". Ezra Pound defines poetry as "... a composition of words set to music" (Pound \& Ford, 1982, p.20). English poetry creates beautiful and musical sound effects through the 
regular repetition of stressed and unstressed syllables, alliteration and rhyme and so on. Let's take Alfred Tennyson's poem The Eagle as an example.

The Eagle

He clasps the crag with crooked hands;

Close to the sun in lonely lands,

Ringed with the azure world, he stands.

The wrinkled sea beneath him crawls;

He watches from his mountain walls,

And like a thunderbolt he falls. (Liu Shoulan, 2003, p.18)

The above short poem displays a strong musical sense. First, the poet mainly utilizes the iambic-tetrameter form of meter, but he changes iambic foot into trochaic foot in the beginning of the second and third lines. In this way, the poem effectively depicts imposing and valiant image of the eagle with slowing down the speed of the lines. Second, the poet makes use of alliteration such as the sound /k/ in the words "clasps," "crag," and "crooked", and /l/ in the words "lonely" and "lands" and so on , assonance such as the sound /æ/ in the words "claps", "crag" and "hands", /ou/ in the words "close" and "lonely" and so on, and rhyme /ændz/ and /o:lz/ to endow the poem with magnificent and tuneful melody. These musical devices not only vividly depict the majestic image of the eagle but also lighten the reader. And the reader may better appreciate the beauty of English if he reads the poem repeatedly and become more interested in learning English.

\section{B. Concise Expressions}

Poetry uses unusual words or uses the words in unusual ways to convey meanings, emotions, or ideas to the reader. Laurence Perrine states that, "Poetry is the most condensed and concentrated form of literature, saying most in the fewest of words than any other forms of literature" (Perrine, 1982, p.9). Poems often make deliberate use of imagery, word association, and sound effects to produce aesthetic effects and evoke the reader's emotion and imagination. Let's take some lines of e. e. cummings' poem in Just - as example.

in Just-

spring when the world is mud-

luscious the little

lame balloonman

whistles far and wee

and eddieandbill come

running from marbles and

piracies and it's

spring

when the world is puddle-wonderful (Liu Shoulan, 2003, p.334)

In the above lines, these few words "mud-luscious", "balloonman', "wee" and "puddle-wonderful" not only endow the spring with color, taste, and vigor but also portray a joyful season and a carefree and pure world of children to the reader. The special formation of words and the meanings of them naturally throw the reader into thinking and imaging of the wonderful season and the vigorous life. So concise expressions in the poetry show the expressiveness of language and can better inspire the reader's emotion and imagination. And the reader will better understand the magical effect of the language and become more interested in learning language in reading poetry.

\section{Rich Images}

Image is a concrete representation of a sense impression, a feeling, or an idea. In some poems one image predominates either by recurring throughout the work or by appearing at a critical point in the plot. Often poets use multiple images throughout a work to suggest states of feeling and to convey implications of thought and action. The charming or the aesthetic effect of the poetry largely depends on the images that the poet carefully chooses to express his or her intentions or feelings. For example,

To Autumn

Season of mists and mellow fruitfulness,

Close bosom-friend of the maturing sun;

Conspiring with him how to load and bless

With fruit the vines that round the thatch-eaves run;

To bend with apples the moss'd cottage-tree,

And fill all fruit with ripeness to the core;

To swell the gourd, and plump the hazel shells

With a sweet kernel; to set budding more,

And still more, later flowers for bees,

Until they think warm days will never cease,

For summer has o'er-brimm'd their clammy cells. (Liu Shoulan, 2003, p.322)

In the above stanza, the poet displays to the reader a charming and colorful harvest season with the images of vision 
(curved vines, ripen apples, moss'd cottage-tree, swelled gourd, plumped shells, budding flowers, busy bees), the images of taste (mellow fruitfulness and sweet kernel), and the images of touching (warm days and clammy cells). And just with these images, the poet endows the autumn with visible, tangible shape and color. Reading the poem, the reader can easily feel the beauty, the power and vigor of the autumn with the help of the images. And the reader may be affected by the vivid images and the feeling that the images convey and will develop a greater interest in poetry and in the language as well.

\section{The Functions OF ENGLISH PoEtRy TEACHING IN EXTENSIVE READING TEACHING}

Like other written materials, English poetry not only can help learners enlarge vocabulary, enhance general language competence, and enrich intercultural knowledge with vivid expressions and cultural information, but also can improve learners' guessing and predicting skills with its special uses of words and deviant forms. In a word, English poetry can be useful material to develop learners' reading competence if it is properly used in teaching. Besides, the author thinks English poetry can efficiently makes up for the deficiency of the traditional extensive reading teaching with its special characteristics.

\section{A. Enhancing Learners'Motivation}

According to Crookes and Schmidt, motivation refers to "interest in and enthusiasm for the materials used in class; persistence with the learning task, as indicated by levels of attention or action for an extended duration; and levels of concentration and enjoyment." (Peacock, 1997, p.145) English poetry can be used to enhance learners' motivation in the following ways. First, learners will be delighted with musical sound effects and can better appreciate the beauty of English and fascination of language of poetry. The more learners read the poem, the greater interest they may show in the language and in learning language. Second, the concise expressions in poetry can inspire learners to explore and appreciate the power of language in conveying meanings. For example, the word "mud-luscious" in the poem in Justnot only suggests it is just after raining but also makes the reader feel the taste of spring. So any careful learner will be delighted by the word and may become more active in learning English. Third, images in poetry can improve learners' appreciation of poetry's aesthetic effects when they fully appreciate the real meaning that the images convey in the poems. In short, English poetry teaching can arouse learners' interest and passion of learning English in class and after class.

\section{B. Stimulating Learners'Imagination}

Reading is related closely with thinking and without thinking there is no reading. Just as Goodman states that "The writer encodes thought as language and a reader decodes language to thought by means of interaction between language and thought in reading". (Goodman, 2006, p.12) And imagination can help the reader read between lines. Imagination is regarded as the mental capacity for experiencing, constructing, or manipulating "mental imagery". It is also regarded as responsible for inventiveness, creative and insightful thought. Imagination not only can help the reader have a better understanding of the reading material and but also can improve readers' inventiveness or creativity as well.

According to Webster's Third New International Dictionary of the English Language, poetry is writing that formulates a concentrated imaginative awareness of experience in language chosen and arranged to create a specific emotional response through its meaning, sound, and rhythm; ....a quality that stirs the imagination or gives a sense of heightened and more meaningful existence. So poetry may be the very useful material to stimulate learners' imagination. For example, the "lame balloonman" in the poem in Just - may let the reader think of the colorful balloons and the walk and the spiritual state of the man carrying the balloons. Reading the poem To Autumn, the reader seems to see the ripen fruits and busy bees and seems to smell the fragrance of fruits and followers. All the images in the poem may inspire the reader to imagine the wonderfulness of the season. Therefore, we can say that poetry is better material to enrich the reader's imagination with its special form and to encourage the reader's creativity compared with prose, novels and other technical materials and so on.

\section{Broadening Learners' Experience}

Poetry mirrors life in a rather indirect and condensed way with deep connotative meaning. It is what is extract from life and is true to life. Just as Perrine says, "Poetry through fascinating description contributes a lot to the store of human experience. Poetry as a whole is concerned with all kinds of experience--beautiful or ugly, strange or common, noble or ignoble, actual or imaginary." (Perrine, 1982, p.9) The experiences or the truth that the poet creates in the poem will make the reader accumulate more experience of life and have a fresh or deep insight of life. For example, Alfred Tennyson' poem The Eagle does not simply tell the reader the story of the eagle but it implies the life of human beings. The line "The wrinkled sea beneath him crawls" indicates that the man should face and struggle bravely with hard surrounding or situation. And e. e. Cummings' poem "in Just-" presents the reader the vigor of spring and the enthusiasm of children and childlike enthusiasm of adults. After reading the poem, the reader may feel life is really splendid like the wonderful spring and will love life more than before.

\section{Improving Learners'Self-cultivation}

Poetry is an art form that presents the reader wonderful things that one may neglect in daily life. Just as Eleanor 
Farjeon puts it in his poem Poetry:

What is poetry? Who knows?

Not a rose,but the scent of the rose;

Not the sky,but the light in the sky;

Not the fly,but the gleam of the fly;

Not the sea,but the sound of the sea;

Not myself,but what makes me

See, hear,and feel something that prose

Cannot: and what it is, who knows? (Yang Limin, Xu Kerong, 1985, p.34)

The above poem shows the nature of poetry and suggests the enjoyment of reading poem. In another word, the reader seems to be enjoying the magnificent scenery or listening to a tuneful melody of the nature when he is appreciating a good poem. In the appreciation of poetry, learners must be affected by the aesthetic effects of poetry and will become very sensitive to art and develop a keen feeling for poetry or genuine art. And poetry always conveys the poet's feeling, as Wordsworth states that poetry is "the spontaneous overflow of powerful feelings recollected in tranquility" (Chang Yaoxin, 2006, p.17). Learners' character will be nurtured by the feeling that the poetry conveys and the learners will become more cultivated and more optimistic to life. Therefore, we can say that poetry teaching can be an effective way to realize the aim of aesthetic education: enliven learners' spiritual life and improve their self-cultivation.

\section{CONCLUSION}

Nowadays, most learners are eager to seek quick success and instant benefits in the present competitive society. They are concerned more about material wealth rather than spiritual needs. Most learners are indifference to the art and to others and the spiritual civilization is worsening day after day at the university campus. In order to change the above situation and the traditional extensive reading teaching that lays much emphasis on learners' linguistic competence, the author thinks it is very significant to apply English poetry to extensive reading teaching.

English poetry, with its aesthetic values, not only is very useful material to improve learners' language competence and motivation of learning English but also is valuable material to enhance learners' imagination and creativity. Furthermore, English poetry can broaden learners' experience of life and improve learners' self-cultivation if English poetry is properly presented in class. First, the teacher should be proficient in English poetry and possess extensive knowledge including the cultural knowledge. Second, the teacher should carefully choose pomes with the linguistic knowledge that is appropriate for learners' English level and also should choose poems of diverse themes-love, nature, youth, society and so on to meet learners' interest. Third, the teacher should use the proper teaching method-student-centered and interactive teaching method to stimulate students' motivation and challenge students' creativity. In a word, English poetry will be very helpful in fulfilling all the ultimate goal of extensive reading teaching which aims at enhancing learners' aesthetic consciousness, creativity and self-cultivation if it is properly used in extensive reading teaching.

\section{REFERENCES}

[1] Brown, H. D. (2001). Principles of Language Learning and Teaching. Beijing: Foreign Language Teaching and Research Press.

[2] Chang Yaoxin. (2006). A Survey of English Literature. Tianjin: Nankai University press.

[3] Csapó, B. (1999). Improving Thinking through the Content of Teaching. In Teaching and Learning Thinking Skills. Ed. Hamers, J. H. M. Van Luit, J. E. H. \& Csapó, B. Swets \& Zeitlinger Publishers: Lisse, the Netherlands, 37-61.

[4] Geoffrey, N. Leech. (2001). A Linguistic Guide to English Poetry. Beijing: Foreign Language and Research Press.

[5] Goodman, K. (2006). The Reading Process. In P.L. Carrell, J. D. Evine, and D. E. Eskey (eds.). Interactive Approaches to Second Language Reading. Shanghai: Shanghai World Book Publishing Company.

[6] Peacock, M. (1997). Authentic Materials and Motivation. In ELT Journal, Vol. 52, No.2: 145-156.

[7] Liu Shoulan. (2003). The Interpretation of British \& American Poetry. Shanghai: Shanghai Foreign Language Education press.

[8] Perrine, L. (1982). Sound and Sense: An Introduction to Poetry. Beijing: Beijing Press.

[9] Pound, E. \& Ford, F. M. (1982). Pound/ Ford, the Story of a Literary Friendship. New York: New Directions Publishing.

[10] Yang Limin, Xu Kerong. (1985). College English (Book 3). Beijing: Foreign Language and Research Press.

Fanmei Kong was born in Linyi, China in 1974. She received her M.A. degree in literature from Shandong University, China in 2009.

She is currently a lecturer in English Department, Dezhou University, Dezhou, China. Her research interest is literary translation. 